\title{
Hypoglycemic Effect of Aqueous and Ethyl Acetate Leaf Extract of Maytenus putterkloides in Alloxan Induced Diabetic Mice
}

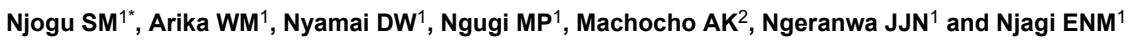 \\ ${ }^{1}$ Department of Biochemistry and Biotechnology, School of Pure and Applied Sciences, Kenyatta University, P.0. Box 43844-00100, Nairobi, Kenya \\ ${ }^{2}$ Department of Chemistry, School of Pure and Applied Sciences, Kenyatta University, P.O. Box 43844-00100, Nairobi, Kenya
}

"Corresponding author: Njogu SM, Department of Biochemistry and Biotechnology, Kenyatta University, P.O. Box 43844-00100, Nairobi, Kenya, Tel: +254722753769; Email: njogusm@gmail.com

Rec date: June 09, 2016; Acc date: June 28, 2016; Pub date: June 30, 2016

Copyright: $@ 2016$ Njogu SM, et al. This is an open-access article distributed under the terms of the Creative Commons Attribution License, which permits unrestricted use, distribution, and reproduction in any medium, provided the original author and source are credited.

\begin{abstract}
Maytenus putterkloides has been used traditionally to manage several diseases including diabetes, however, its efficacy has not been scientifically evaluated. The aim of this study was to determine the in vivo hypoglycemic activity of aqueous and ethyl acetate leaf extract of this plant in male swiss white albino mice. The antidiabetic activity was screened in alloxan induced diabetic mice through oral and intraperitoneal routes. Phytochemical composition was assessed using standard procedures. The aqueous and ethyl acetate leaf extract of this plant showed hypoglycemic activity at dose levels of $50,100,200,300 \mathrm{mg} / \mathrm{kg}$ body weight in a dose independent manner via both routes. The extracts contained total phenolics, saponins, tannins, flavonoids, alkaloids and phytonutrients; vitamins B1, B3, and C. The observed hypoglycemic activity could be associated with the phytochemicals present in this plant extract.
\end{abstract}

Keywords: Diabetes mellitus; Maytenus putterkloides; Hypoglycemic activity; Antidiabetic; Alloxan

\section{Introduction}

Diabetes mellitus is a chronic metabolic disorder characterized by hyperglycemia and glucose intolerance, either as a result of insulin deficiency or impaired effectiveness of insulin's action, or to a combination of both factors [1]. The prevalence of diabetes is increasing rapidly worldwide and it has been predicted that by 2030 the number of adults with diabetes would have almost doubled worldwide, from 177 million in 2000 to 370 million [2].

Diabetes mellitus may present with characteristic symptoms such as thirst, polyuria, blurring of vision, and weight loss [3]. In its most severe forms, ketoacidosis or a non-ketotic hyperosmolar state may develop and lead to stupor, coma and, in absence of effective treatment, death. Among the complications associated with diabetes mellitus include microvascular complications which mainly affect the retina, kidney and peripheral nervous system and may progress to more overt serious complications, and macrovascular complications, mainly atherosclerosis, that may lead to cerebrovascular ischemia and stroke $[3,4]$.

Normal fasting plasma glucose levels ranges between 3.5-6.7 mmol/l (63-120.6 mg/dl). After a meal the blood glucose level rises to approximately $8 \mathrm{mmol} / \mathrm{l}$ and rarely exceeds this level. Repeated fasting blood glucose levels $\geq 7.0 \mathrm{mmol} / \mathrm{l}(126 \mathrm{mg} / \mathrm{dl})$ or 2-hour postprandial glucose values $\geq 11.1 \mathrm{mmol} / \mathrm{l}(200 \mathrm{mg} / \mathrm{l})$ is considered to be diagnostic criteria for diabetes and correlates with HbAlc threshold of 6.5\% [3]. Currently available therapy for diabetes include insulin and various oral antidiabetic agents such as sulphonylureas, metformin, $\alpha$ glucosidase inhibitors, troglitazone [5]. These drugs are used as monotherapy or in combination to achieve better glycemic control. However, the use of the above oral agents causes a number of serious adverse effects which includes digestive disorders (nausea, vomiting), blood disorders (hemolytic anemia) and hypoglycemia [6]. As a consequence there continues to be the high demand for new oral anti-diabetic drug with little or no side effect from herbal sources $[7,8]$.

According to World Health Organization (WHO), up to $80 \%$ of the world's population in developing countries relies on traditional medicine practices for their primary health care needs [9]. Plants have always been used to treat many diseases throughout the world. They contain a great diversity of bioactive compounds which makes them a possible source for different types of drugs [10]. Plants are well known in traditional herbal medicine for their hypoglycemic activities and available literatures indicate that there are more than 800 plant species showing hypoglycemic activity [11]. For example the widely used hypoglycemic drug metformin is originally derived from the medicinal plant Galega officinalis [12]. There has been increasing demand for the use of plant products with anti-diabetic activity due to its low cost, easy availability and less side effects. Therefore plant materials are continuously scrutinized and explored for their effects as hypoglycemic agents [13]. In the forkloric set up, hot water extract of $M$. putterkloides has been reported to manage diabetes mellitus; however, there is no documented scientific investigation that has been conducted to ascertain the validity of this claim. Therefore, this study was carried out to determine the in vivo hypoglycemic activity of aqueous and ethyl acetate leaf extract of $M$. putterkloides in alloxanized diabetic male mice.

\section{Materials and methods}

\section{Study site}

This study was undertaken at the Department of Biochemistry and Biotechnology, School of Pure and Applied Sciences, Kenyatta University. Kenyatta University is $23 \mathrm{~km}$ from Nairobi off Thika Road. 


\section{Collection of the plant materials}

The plant used in this study was collected from its natural habitat in Siakago village, Embu County, Kenya. An acknowledged authority in taxonomy authenticated the botanical identity of the plant and a voucher specimen was deposited at the National Museums of Kenya Herbarium, Nairobi. A traditional medical practitioner provided the information on which plant to collect, what part to collect, and the precise locality where it grows.

The collected plant leaves were dried under shed at room temperature for 1 month, and then ground into powder using an electric mill. The powdered plant material was kept at room temperature away from direct sunlight in closed dry plastic bags.

\section{Preparation of the aqueous extract}

One hundred grams of the powdered plant material was extracted in 1 liter distilled water at $60^{\circ} \mathrm{C}$ for $6 \mathrm{hr}$. The mixture was left to cool at room temperature and then decanted into dry clean conical flask through folded cotton gauze stuffed into a funnel. The decanted extract was then filtered using filter papers under vacuum pump. The filtrate was then freeze-dried for $72 \mathrm{hr}$. The freeze-dried powder was then weighed and stored in airtight container at $-20^{\circ} \mathrm{C}$ until used for bioassay.

\section{Preparation of the ethyl acetate extract}

Similarly, $100 \mathrm{~g}$ of leaf powder was extracted in 1 liter of ethyl acetate at room temperature in a metabolic shaker for six hours. The extracts were filtered with a Whatman filter No 540 and the filtrate was evaporated in rotary evaporator. The extract was weighed and stored in airtight, amber containers at $4^{\circ} \mathrm{C}$ ready for use.

\section{Experimental animals}

The study used male Swiss White Albino mice (3-6 weeks old) that weighed 23-27 g with a mean weight of $25 \mathrm{~g}$. These were bred in the Animal house at the Department of Biochemistry and Biotechnology of Kenyatta University. The mice were housed at a temperature of $250^{\circ} \mathrm{C}$ with $12 \mathrm{hr} / 12 \mathrm{hr}$ darkness photoperiod and fed on rodent pellets and water ad libitum. The experimental protocols and procedures used in this study were approved by the Ethics Committee for the Care and Use of Laboratory Animals of Kenyatta University, Kenya.

Hyperglycemia was induced experimentally by a single intraperitoneal administration of $186.9 \mathrm{mg} / \mathrm{kg}$ body weight of a freshly prepared $10 \%$ alloxan monohydrate (2,4,5,6 tetraoxypyrimidine; 5-6dioxyuracil) obtained from Sigma (Steinhein, Switzerland) [6]. $48 \mathrm{hr}$ after alloxan administration, blood glucose level was measured using a glucometer. Mice with blood glucose levels above $200 \mathrm{mg} / \mathrm{l}$ (or $\geq 11.1$ $\mathrm{mmol} / \mathrm{l}$ ) were considered diabetic and used in this study. Prior to initiation of this experiment, the animals were fasted for 8-12 hr [14] but allowed free acess to water until the end of this experiment.

\section{Experimental design}

For either intraperitoneal or oral route of drug administration, the experimental mice were randomly divided into seven groups of five animals each. Group I consisted of normal mice either intraperitoneally or orally administered with $0.1 \mathrm{ml}$ physiological saline; Group II consisted of alloxan induced diabetic mice either intraperitoneally or orally administered with $0.1 \mathrm{ml}$ physiological saline; Group IIIa consisted of alloxan induced diabetic mice intraperitoneally administered with 0.025 insulin units ( 0.25 insulin units in $1 \mathrm{ml})$ ( $1 \mathrm{IU} / \mathrm{kg}$ body weight) in $0.1 \mathrm{ml}$ physiological saline; Group IIIb consisted of alloxan induced diabetic mice orally administered with $0.075 \mathrm{mg}$ glibenclamide $(0.75 \mathrm{mg}$ in $1 \mathrm{ml})(3 \mathrm{mg} / \mathrm{kg}$ body weight) in $0.1 \mathrm{ml}$ physiological saline; Group IV consisted of alloxan induced diabetic mice either intraperitoneally or orally administered with $1.25 \mathrm{mg}$ extract $(12.5 \mathrm{mg}$ in $1 \mathrm{ml}$ physiological saline) $(50 \mathrm{mg} / \mathrm{kg}$ body weight) in $0.1 \mathrm{ml}$ physiological saline; Group V consisted of alloxan induced diabetic mice either intraperitoneally or orally administered with $2.5 \mathrm{mg}$ extract $(25 \mathrm{mg}$ extract in $1 \mathrm{ml}$ physiological saline) $(100 \mathrm{mg} / \mathrm{kg}$ body weight $)$ in $0.1 \mathrm{ml}$ physiological saline; Group VI consisted of alloxan induced diabetic mice either intraperitoneally or orally administered with $5 \mathrm{mg}$ extract $(50 \mathrm{mg}$ extract in $1 \mathrm{ml}$ physiological saline) $(200 \mathrm{mg} / \mathrm{kg}$ body weight $)$ in $0.1 \mathrm{ml}$ physiological saline; Group VII consisted of alloxan induced diabetic mice either intraperitoneally or orally administered with $7.5 \mathrm{mg}$ extract (75 mg extract in $1 \mathrm{ml}$ physiological saline) (300 mg/kg body weight) in $1 \mathrm{ml}$ physiological saline. $0.1 \mathrm{ml}$ of either insulin or glibenclamide or the plant extract solution was administered either intraperitoneally or orally to each experimental mouse.

\section{Blood sampling and blood glucose determination}

Blood sampling was done by sterilizing the tail with $10 \%$ alcohol and then nipping the tail at the start of the experiment and repeated after 2, 4, 6, 8 and $24 \mathrm{hr}$. Bleeding was enhanced by gently "milking" the tail from the body towards the tip. After the operation, the tips of the tail were sterilized by swabbing with $70 \%$ ethanol. The blood glucose levels were determined with a glucose analyser model (Hypogaurd, Woodbridge, England).

\section{Phytochemical studies}

The extract was analyzed for the following phytochemicals; total phenolics, saponins, tannins, flavonoids, alkaloids and phytonutrients; vitamins $\mathrm{B} 1, \mathrm{~B} 3$, and $\mathrm{C}$ according to the method described by Roy, 2015 [15].

\section{Statistical analysis}

All the data was recorded as mean \pm standard deviation (SD) of the blood glucose levels. One-way ANOVA and post-ANOVA (Tukey's post hoc test) was used to compare the means of untreated normal control mice with diabetic mice treated with saline, diabetic mice treated with the conventional drug, and diabetic mice treated with plant extracts at doses of 50, 100 and $200 \mathrm{mg}$ per kg body weight. $\mathrm{P} \leq$ 0.05 was considered statistically significant.

\section{Results}

\section{Effect of oral and intraperitoneal administration of aqueous leaf extract of $M$. putterkloides on blood glucose levels in alloxan induced diabetic mice}

The dry powder of $M$. putterkloides yielded 5\% (w/w) aqueous leaf extract. Treatment with the aqueous leaf extract showed hypoglycemic properties in alloxan induced diabetic mice (Tables 1 and 2; Figures 1 and 2). Oral administration of the extract lowered the blood glucose levels at all the four tested dose levels $(50,100,200$ and $300 \mathrm{mg} / \mathrm{kg}$ body weight) in a dose independent manner. As shown in Figure 2, the 
Citation: Njogu SM, Arika WM, Nyamai DW, Ngugi MP, Machocho AK, et al. (2016) Hypoglycemic Effect of Aqueous and Ethyl Acetate Leaf Extract of Maytenus putterkloides in Alloxan Induced Diabetic Mice. J Diabetes Metab 7: 685. doi:10.4172/2155-6156.1000685

Page 3 of 7

aqueous leaf extract of $M$. putterkloides decreased the blood glucose levels appreciably by the four therapeutic doses from the $2^{\text {nd }}$ to the $8^{\text {th }}$ hour. In the $24^{\text {th }}$ hour the plant extract had lost its hypoglycemic effect and the animals started regaining their diabetic states.

\begin{tabular}{|c|c|c|c|c|c|c|}
\hline Treatment Groups & $0 \mathrm{hr}$ & $2 \mathrm{hr}$ & $4 \mathrm{hr}$ & $6 \mathrm{hr}$ & $8 \mathrm{hr}$ & $24 \mathrm{hr}$ \\
\hline Normal Control & $5.12 \pm 0.04$ & $5.16 \pm 0.02^{d}$ & $5.14 \pm 0.04^{b}$ & $5.12 \pm 0.02^{b}$ & $5.12 \pm 0.04^{b}$ & $5.12 \pm 0.04^{c}$ \\
\hline Diabetic control & $15.26 \pm 1.14$ & $16.66 \pm 1.31^{a}$ & $17.58 \pm 1.33^{a}$ & $19.18 \pm 1.42^{a}$ & $19.98 \pm 1.43^{a}$ & $23.46 \pm 1.00^{a}$ \\
\hline Reference group & $14.80 \pm 1.40$ & $7.54 \pm 0.29 \mathrm{~cd}$ & $6.46 \pm 0.29 b$ & $5.42 \pm 0.22 b$ & $4.88 \pm 0.09 b$ & $7.06 \pm 0.22 b c$ \\
\hline $50 \mathrm{mg} / \mathrm{kg}$ bw & $14.82 \pm 1.37$ & $11.96 \pm 0.96^{\mathrm{bc}}$ & $7.60 \pm 0.56^{b}$ & $6.72 \pm 0.39^{b}$ & $6.02 \pm 0.35^{b}$ & $10.32 \pm 0.85^{b}$ \\
\hline $100 \mathrm{mg} / \mathrm{kg}$ bw & $15.16 \pm 1.01$ & $10.24 \pm 0.84^{\mathrm{bc}}$ & $8.20 \pm 0.76^{b}$ & $6.20 \pm 0.33^{b}$ & $5.10 \pm 0.14^{b}$ & $9.46 \pm 0.71^{b}$ \\
\hline 200 mg/kg bw & $16.02 \pm 1.94$ & $12.26 \pm 1.81^{\mathrm{ab}}$ & $8.22 \pm 1.08^{b}$ & $6.24 \pm 0.78^{b}$ & $5.26 \pm 0.56^{b}$ & $9.28 \pm 1.42^{b}$ \\
\hline 300 mg/kg bw & $14.94 \pm 1.38$ & $11.80 \pm 0.92^{\mathrm{bc}}$ & $8.46 \pm 0.66^{b}$ & $6.30 \pm 0.45^{b}$ & $5.14 \pm 0.36^{b}$ & $7.68 \pm 0.77^{\mathrm{bc}}$ \\
\hline
\end{tabular}

Table 1: Effects of intraperitoneally administered aqueous leaf extract of M.utterkloides on blood glucose levels in alloxan induced diabetic mice $(\mathrm{mmol} / \mathrm{l})$.

\begin{tabular}{|c|c|c|c|c|c|c|}
\hline Treatment Groups & $0 \mathrm{hr}$ & $2 \mathrm{hr}$ & $4 \mathrm{hr}$ & $6 \mathrm{hr}$ & $8 \mathrm{hr}$ & $24 \mathrm{hr}$ \\
\hline Normal Control & $5.12 \pm 0.07$ & $5.12 \pm 0.04^{b}$ & $5.16 \pm 0.02^{c}$ & $5.22 \pm 0.02^{b}$ & $5.18 \pm 0.04^{b}$ & $5.08 \pm 0.04^{d}$ \\
\hline Diabetic control & $13.76 \pm 1.40$ & $15.54 \pm 1.69^{a}$ & $17.18 \pm 1.59^{a}$ & $18.28 \pm 1.50^{a}$ & $19.58 \pm 1.69^{a}$ & $21.48 \pm 1.56^{a}$ \\
\hline Reference group & $14.84 \pm 1.36$ & $12.26 \pm 1.47^{a}$ & $9.36 \pm 1.26^{\mathrm{bc}}$ & $7.28 \pm 0.71^{b}$ & $5.30 \pm 0.26^{b}$ & $7.48 \pm 0.21^{\mathrm{cd}}$ \\
\hline $50 \mathrm{mg} / \mathrm{kgbw}$ & $14.56 \pm 1.28$ & $12.20 \pm 0.55^{a}$ & $9.66 \pm 0.40^{\mathrm{b}}$ & $8.66 \pm 0.63^{b}$ & $7.70 \pm 0.81^{b}$ & $10.96 \pm 0.44^{b c}$ \\
\hline $100 \mathrm{mg} / \mathrm{kgbw}$ & $14.42 \pm 0.94$ & $12.50 \pm 0.87^{a}$ & $9.86 \pm 1.02^{b}$ & $8.46 \pm 0.92^{b}$ & $5.50 \pm 0.67^{b}$ & $11.26 \pm 0.8^{1 b}$ \\
\hline $200 \mathrm{mg} / \mathrm{kgbw}$ & $14.00 \pm 1.43$ & $11.80 \pm 1.22^{\mathrm{a}}$ & $9.06 \pm 0.87^{\mathrm{bc}}$ & $7.38 \pm 0.46^{b}$ & $6.20 \pm 0.37^{b}$ & $9.16 \pm 0.76^{b c}$ \\
\hline 300 mg/kgbw & $13.04 \pm 0.97$ & $10.94 \pm 0.79^{a}$ & $9.06 \pm 0.46^{b c}$ & $7.00 \pm 0.43^{b}$ & $5.50 \pm 0.67^{b}$ & $11.24 \pm 0.92^{\mathrm{b}}$ \\
\hline
\end{tabular}

Table 2: Effects of orally administered aqueous leaf extract of $M$. putterkloides on blood glucose levels in alloxan induced diabetic mice (mmol/l).
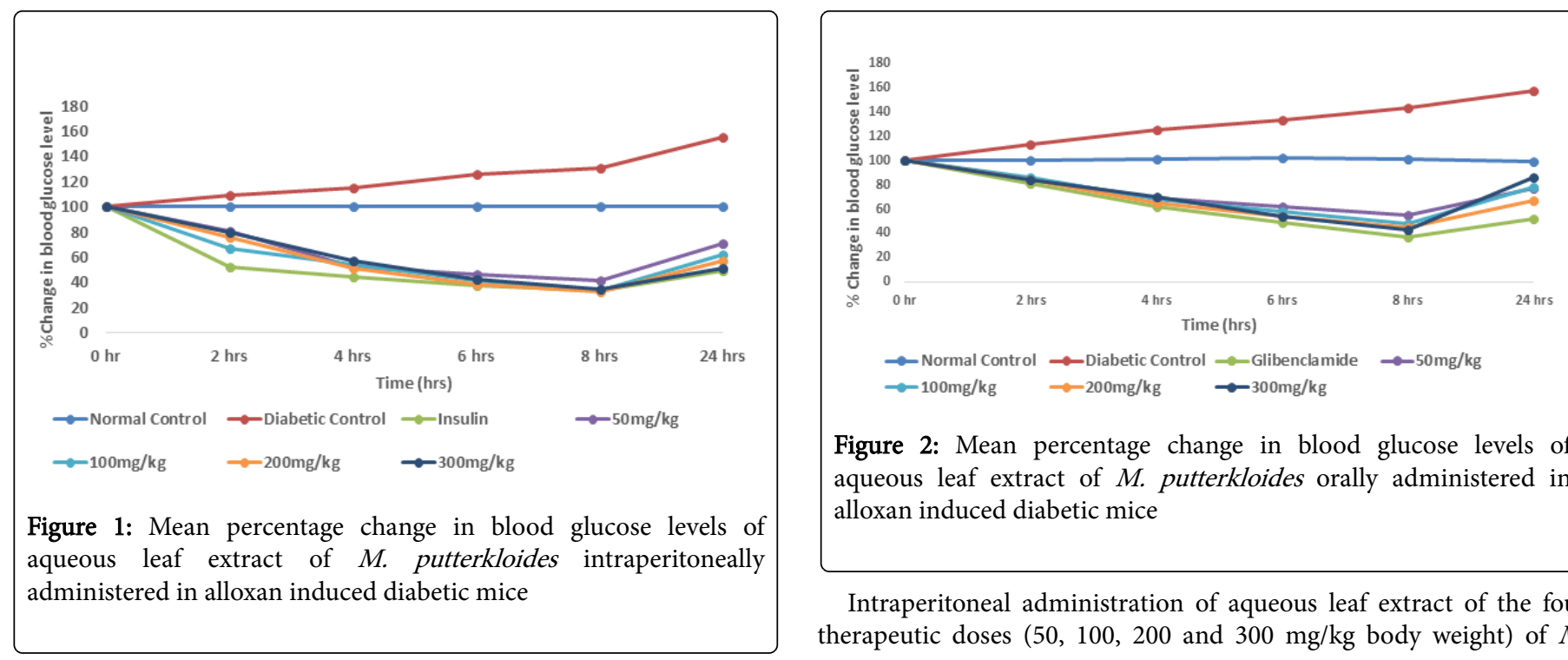

Figure 2: Mean percentage change in blood glucose levels of aqueous leaf extract of $M$. putterkloides orally administered in alloxan induced diabetic mice

Intraperitoneal administration of aqueous leaf extract of the four therapeutic doses $(50,100,200$ and $300 \mathrm{mg} / \mathrm{kg}$ body weight) of $M$. 
Page 4 of 7

putterkloides also lowered blood glucose levels from the $2^{\text {nd }}$ hour to the $8^{\text {th }}$ hour (Table 1; Figure 1). By the $2^{\text {nd }}$ hour the four therapeutic doses of the extract had lowered the blood glucose levels to $81.12 \%$, $67.43 \%, 75.52 \%$, and $79.51 \%$, respectively, compared to insulin which had lowered blood sugar levels to $52.10 \%$ within the same hour. In the 6th hour the percent blood glucose reductions by the four therapeutic doses of the extract were at $46.13 \%, 41.26 \%, 38.96 \%$ and $42.60 \%$, respectively, compared to insulin which had lowered blood sugar levels to $37.71 \%$ within the same hour. After this, a gradual increase was recorded up to the twenty fourth hour.

\section{Effect of oral and intraperitoneal administration of ethyl acetate leaf extract of $M$. putterkloides on blood glucose levels in alloxan induced diabetic mice}

Intraperitoneally administered aqueous leaf extract of $M$. putterkloides decreased the blood glucose levels at all the four doses of 50, 100, 200 and $300 \mathrm{mg} / \mathrm{kg}$ body weight (Table 3; Figure 3). The extract caused a steady decline in blood glucose levels from the second to eighth hour. In the $24^{\text {th }}$ hour, there was a gradual increase in blood glucose levels. However, the sugar levels were not reduced in a dose dependent manner.

\begin{tabular}{|c|c|c|c|c|c|c|}
\hline Treatment Groups & $0 \mathrm{hr}$ & $2 \mathrm{hr}$ & $4 \mathrm{hr}$ & $6 \mathrm{hr}$ & $8 \mathrm{hr}$ & $24 \mathrm{hr}$ \\
\hline Normal Control & $5.16 \pm 0.05$ & $5.22 \pm 0.04^{\mathrm{c}}$ & $5.22 \pm 0.04^{c}$ & $5.22 \pm 0.02^{d}$ & $5.14 \pm 0.02^{\mathrm{C}}$ & $5.18 \pm 0.05^{d}$ \\
\hline Diabetic control & $14.26 \pm 1.39$ & $16.22 \pm 1.54^{a}$ & $17.74 \pm 1.71^{\mathrm{a}}$ & $19.74 \pm 1.61^{a}$ & $21.20 \pm 1.57^{a}$ & $22.72 \pm 1.34^{a}$ \\
\hline Reference group & $14.60 \pm 1.20$ & $6.68 \pm 0.30^{b c}$ & $5.96 \pm 0.12^{\mathrm{c}}$ & $5.52 \pm 0.12^{c d}$ & $5.14 \pm 0.10^{c}$ & $7.020 \pm 0.30^{\mathrm{cd}}$ \\
\hline $50 \mathrm{mg} / \mathrm{kg} \mathrm{bw}$ & $13.92 \pm 1.31$ & $13.22 \pm 1.32^{a}$ & $12.00 \pm 1.46^{a b}$ & $10.86 \pm 1.49^{b c}$ & $9.50 \pm 1.34^{\mathrm{bc}}$ & $11.58 \pm 1.24^{b}$ \\
\hline $100 \mathrm{mg} / \mathrm{kg} \mathrm{bw}$ & $13.38 \pm 1.32$ & $12.44 \pm 1.04^{\mathrm{ab}}$ & $10.96 \pm 1.09 \mathrm{bc}$ & $10.24 \pm 1.23^{\mathrm{bcd}}$ & $9.46 \pm 1.19^{b c}$ & $11.08 \pm 0.93^{b c}$ \\
\hline $200 \mathrm{mg} / \mathrm{kg}$ bw & $15.92 \pm 2.03$ & $13.26 \pm 1.87^{a}$ & $11.96 \pm 1.75^{\mathrm{ab}}$ & $11.26 \pm 1.56^{b}$ & $10.92 \pm 1.52^{\mathrm{b}}$ & $10.76 \pm 1.16^{b c}$ \\
\hline $300 \mathrm{mg} / \mathrm{kg}$ bw & $15.54 \pm 2.29$ & $13.72 \pm 1.82^{\mathrm{a}}$ & $11.96 \pm 1.67^{\mathrm{ab}}$ & $11.06 \pm 1.35^{b}$ & $10.40 \pm 1.37 b^{c}$ & $11.32 \pm 1.19^{b c}$ \\
\hline
\end{tabular}

Values are expressed as Mean \pm SEM. Values followed by the same superscript are not significantly different ( $p>0.05$; One way ANOVA followed by Tukey's post hoc test)

Table 3: Effects of intraperitoneally administered ethyl acetate leaf extract of $M$. putterkloides on blood glucose levels in alloxan induced diabetic mice $(\mathrm{mmol} / \mathrm{l})$.

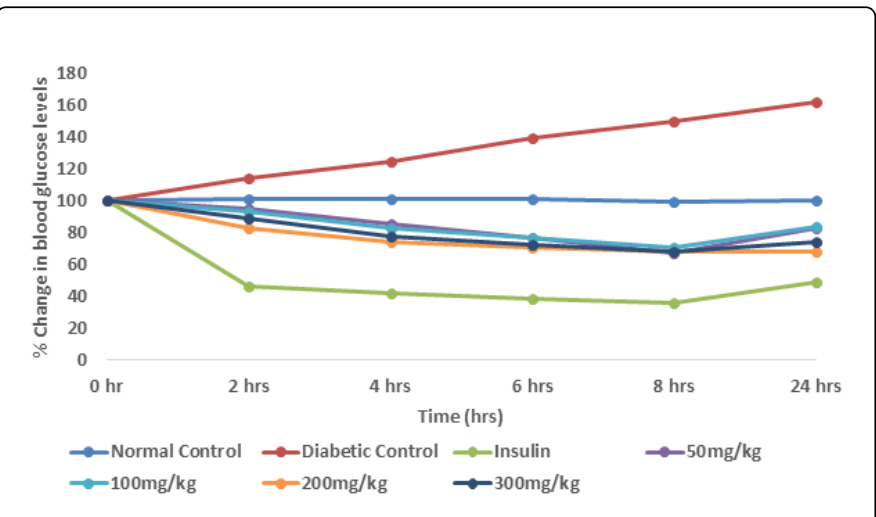

Figure 3: Mean percentage change in blood glucose levels of ethyl acetate leaf extract of $M$. putterkloides intraperitoneally administered in alloxan induced diabetic mice

As depicted in Figure 4 and Table 4, the ethyl acetate leaf extract of M. putterkloides at dose levels of 50 and $200 \mathrm{mg} / \mathrm{kg}$ body weight demonstrated a significant hyperglycemic activity from the $2^{\text {nd }}$ hour up to the $8^{\text {th }}$ hour while at 100 and $300 \mathrm{mg} / \mathrm{kg}$ body weight the extract caused a reduction in blood sugar levels during the same period. By the sixth hour the extract had increased the blood glucose levels to $122.40 \%$ and $117.46 \%$ (50 and $200 \mathrm{mg} / \mathrm{kg}$ respectively) and reduced to $91.51 \%$ and $87.63 \%$ (100 and $300 \mathrm{mg} / \mathrm{kg}$ respectively) for the four doses, compared to $56.77 \%$ decrease in blood sugar levels for the conventional oral drug, glibenclamide (Figure 4).

\section{Phytochemicals composition in $M$. putterkloides}

The phytochemicals detected in the leaf powder of M. putterkloides were total phenolics, saponins, tannins, flavonoids and alkaloids. The leaves extract were found to contain the following macronutrients in significant amounts; vitamin B1 and B3 and vitamin C (Table 5).

\section{Discussion}

The present study investigated the in vivo hypoglycemic activity of ethyl acetate and aqueous leaf extract of M. putterkloides in alloxaninduced diabetic mice. The alloxan destroys and reduces the pancreatic $\beta$-cell population via formation of reactive oxygen species like nitric oxide [14]. The observation that both the leaf ethyl acetate and aqueous extracts of $\mathrm{M}$. putterkloides in various dosage modes lowered blood glucose indicates that this extract has hypoglycemic constituents.

The possible mechanism through which the extract might have brought about blood glucose lowering effect were either by increasing utilization of glucose or by direct stimulation of glucose uptake through increased insulin secretion [15]. It might also have been due to the extract stimulating $\beta$ cells in islet of Langerhans, increased serum insulin and reduced blood sugar [16]. Glucose lowering effect might also be attributed to the increased release of insulin from regenerated $\beta$-cells $[17,18]$, restored insulin sensitivity [19], interference on absorption of dietary carbohydrates as well as disaccharides in small intestine [20] or facilitated utilization of glucose by peripheral tissues mediated by GLUT-4, an insulin dependent glucose transporter [21]. The lowering of blood glucose levels by $M$. putterkloides in the same manner regardless of the dosage might 
Citation: Njogu SM, Arika WM, Nyamai DW, Ngugi MP, Machocho AK, et al. (2016) Hypoglycemic Effect of Aqueous and Ethyl Acetate Leaf

suggest that the extract may reflect uptake of the active constituents through saturable active transport; it may also reflect maximum hypoglycemic activity at the lowest dose used $(50 \mathrm{mg} / \mathrm{kg}$ body weight).

\begin{tabular}{|c|c|c|c|c|c|c|}
\hline Treatment Groups & $0 \mathrm{hr}$ & $2 \mathrm{hr}$ & $4 \mathrm{hr}$ & $6 \mathrm{hr}$ & $8 \mathrm{hr}$ & $24 \mathrm{hr}$ \\
\hline Normal Control & $5.28 \pm 0.07$ & $5.34 \pm 0.08^{b}$ & $5.24 \pm 0.08^{c}$ & $5.20 \pm 0.05^{d}$ & $5.20 \pm 0.04^{c}$ & $5.18 \pm 0.08^{d}$ \\
\hline Diabetic control & $14.48 \pm 1.74$ & $16.78 \pm 1.52^{\mathrm{a}}$ & $19.52 \pm 1.64^{a}$ & $21.18 \pm 1.69^{a}$ & $22.96 \pm 1.50^{\mathrm{a}}$ & $25.60 \pm 1.34^{\mathrm{a}}$ \\
\hline Reference group & $16.18 \pm 2.00$ & $13.08 \pm 1.38^{a}$ & $8.94 \pm 1.06^{b c}$ & $6.76 \pm 0.51^{\mathrm{cd}}$ & $5.46 \pm 0.27^{c}$ & $7.60 \pm 0.36^{\mathrm{cd}}$ \\
\hline 50 mg/kgbw & $12.80 \pm 1.41$ & $13.64 \pm 1.67^{a}$ & $14.48 \pm 2.39^{\mathrm{ab}}$ & $15.94 \pm 2.91^{\mathrm{abc}}$ & $18.22 \pm 3.88^{\mathrm{ab}}$ & $17.44 \pm 3.31^{\mathrm{ab}}$ \\
\hline $100 \mathrm{mg} / \mathrm{kgbw}$ & $14.28 \pm 1.45$ & $14.02 \pm 1.41^{\mathrm{a}}$ & $13.50 \pm 1.63^{\mathrm{abc}}$ & $13.10 \pm 1.81^{\mathrm{abcd}}$ & $13.10 \pm 1.87^{a b c}$ & $15.62 \pm 1.91^{b c}$ \\
\hline $200 \mathrm{mg} / \mathrm{kgbw}$ & $13.96 \pm 1.77$ & $15.76 \pm 2.92^{\mathrm{a}}$ & $16.24 \pm 3.35^{\mathrm{ab}}$ & $17.36 \pm 4.09^{a b}$ & $16.62 \pm 3.57^{a b}$ & $17.10 \pm 3.27^{\mathrm{ab}}$ \\
\hline $300 \mathrm{mg} / \mathrm{kgbw}$ & $11.34 \pm 1.22$ & $10.46 \pm 1.28^{\mathrm{ab}}$ & $10.22 \pm 1.29^{b c}$ & $9.92 \pm 1.37^{\mathrm{bcd}}$ & $9.66 \pm 1.25^{b c}$ & $11.24 \pm 1.06^{\mathrm{bcd}}$ \\
\hline
\end{tabular}

Table 4: Effects of orally administered aqueous leaf extract of M. putterkloides on blood glucose levels in alloxan induced diabetic mice (mmol/l).

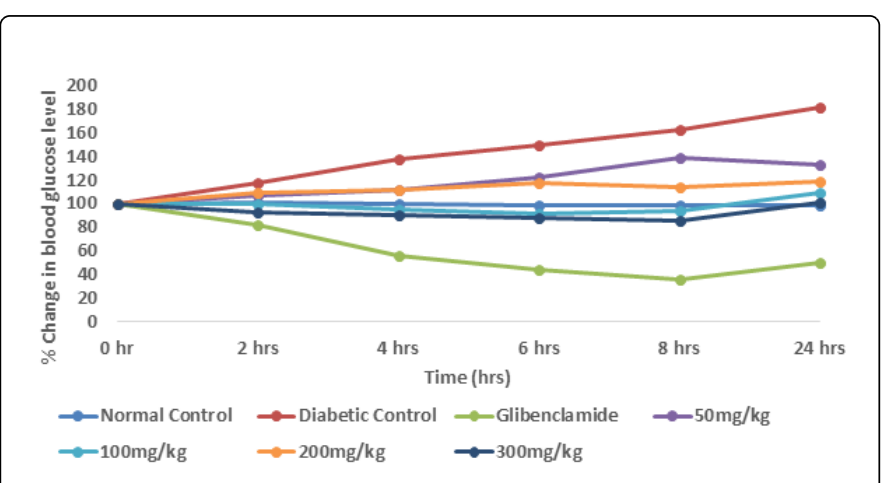

Figure 4: Mean percentage change in blood glucose levels of ethyl acetate leaf extract of $M$. putterkloides orally administered in alloxan induced diabetic mice

\begin{tabular}{|l|l|l|}
\hline \multicolumn{2}{|l|}{ Phytochemical constituents of M. putterkloides } \\
\hline Phytochemicals & $\begin{array}{l}\text { Absorbance } \\
(\mathrm{nm})\end{array}$ & Mean concentration $(\mathrm{mg} / \mathrm{kg})$ \\
\hline Total phenols & 650 & $526.52 \pm 0.05$ \\
\hline Tannins & 700 & $24.94 \pm 0.01$ \\
\hline Saponins (\%) & - & $7.66 \pm 0.18$ \\
\hline Flavanoids & 650 & $46.40 \pm 0.01$ \\
\hline Alkaloids (\%) & - & $5.76 \pm 0.15$ \\
\hline Vitamin C & - & $25.40 \pm 4.72$ \\
\hline Vitamin B1 & - & $13.43 \pm 1.95$ \\
\hline Vitamin B3 & - & - \\
\hline
\end{tabular}

Table 5: Phytochemical composition of $M$. putterkloides
The observation that the two tested doses of ethyl acetate leaf extracts of $M$. putterkloides at 50 and $200 \mathrm{mg} / \mathrm{kg}$ body weight dose raised the glucose levels to beyond that of the diabetic control mice suggests that the extract constituents may either have triggered gluconeogenesis together with glycogenolysis or could have had constituents which promoted further death of the pancreas. The observation that both the leaf ethyl acetate (intraperitoneal route) and aqueous extracts (intraperitoneal or oral routes) of $M$. putterkloides in various dosage modes, the sugar levels started rising from the eighth to the twenty fourth hour in all therapeutic dosages may have been due to the extract having a short half-life or the extract may have been prone to fast hepatic metabolism and renal clearance [1].

The hypoglycemic effect of this plant could be associated with the presence total phenolics, saponins, tannins, flavonoids and alkaloids which have been associated with hypoglycemic activity [22]. The alkaloid 1-ephedrine promotes the regeneration of pancreatic islets following destruction of the beta cells, hence restoring the secretion of insulin and thus correcting hyperglycemia [22]. The tannin epigallocatechin-3-gallate exhibits anti-diabetic activity as demonstrated by Broadhurst et al. [23]. Flavonoids isolated from leaf of Ipomoea batatas, ameliorated blood glucose level and lipid parameters in alloxan induced diabetic mice at $50-150 \mathrm{mg} / \mathrm{kg}$ [24]. Flavonoid fraction from Pterocarpus marsupium has been shown to cause pancreatic beta cell regranulation.

Saponins are glycosides of triterpenes, steroids or alkaloids. Previous researchers have demonstrated the hypoglycemic activity of triterpenoid glycosides [25,26]. Presence of saponins in this extract could also be responsible for the hypogycemic activity. For instance ginseng and its saponins have been shown to lower blood glucose in alloxan-treated, genetically diabetic, and normal mice [26]. Clinically all the forms of tannin may participate in managing glucose level in blood. Tannin stimulates the receptor cells to utilize carbohydrate [27].

The hypoglycemic activity observed could also be due to the presence of various macronutrients such as vitamin B1 and B3 and vitamin $\mathrm{C}$ which are strong antioxidants and have been known to manage diabetes mellitus. They do so by neutralizing the reactive oxygen species (hydroxyl and superoxide radicals, hydrogen peroxide, 
lipid peroxides) generated during the induction of diabetes by alloxan by helping the pancreatic cells to regenerate and hence helping to maintain optimal cellular and systemic health and well-being of the mice [28]. These antioxidants interact and synergistically stabilize, or deactivate, free radicals before they attack cells [29]. Antioxidants are responsible for most of the biological activities of phytochemicals including antidiabetic, anti-inflammatory, antiallergenic, antiviral, anti-aging and anti-carcinogenic activities [30,31].

\section{Conclusion}

In conclusion, the findings of this study indicate that, oral administration of ethyl acetate leaf extract of $M$. putterkloides at doses of 50 and $200 \mathrm{mg} / \mathrm{kg}$ body weight, respectively demonstrated hypoglycemic activity while 100 and $300 \mathrm{mg} / \mathrm{kg}$ lowered blood sugar levels in a dose independent. The aqueous leaves demonstrated hypoglycemic activity in a dose independent in all therapeutic dose levels in both routes. The observed hypoglycemic activity could be associated with the phytochemicals and phytonutrients present in $M$. putterkloides. The study recommends continued use of $M$. putterkloides in the management of diabetes and support the folkloric claim. Also the study finding opens an avenue for the conservation to ensure that its continued use is sustainable.

\section{Acknowledgement}

The authors wish to acknowledge the department of Biochemistry and Biotechnology, Kenyatta University for allowing us to use the departmental animal house facility for mice breeding and performing the efficacy studies; the technical support from Mr. James Adino of the department of Medical Laboratory Sciences and Mr. Wycliffe Wenwa from department of Biochemistry and Biotechnology, Kenyatta University.

\section{References}

1. Arika WM, Abdirahman YA, Mawia MM, Wambua KF, Nyamai DM (2015) Hypoglycemic Effect of Lippia javanica in Alloxan Induced Diabetic Mice. J Diabetes Metab 6: 2 .

2. International Diabetes Federation (2013) IDF Diabetes Atlas 2: 15-19.

3. Kerner W, Brückel J; German Diabetes Association (2014) Definition, classification and diagnosis of diabetes mellitus. Exp Clin Endocrinol Diabetes 122: 384-386.

4. Piero MN, Njagi JM, Kibiti CM, Ngeranwa JJN, Njagi ENM (2012) Metabolic Complications of Diabetes Mellitus: A Review. South Asian Journal of Biological Science 2: 37- 49.

5. Kameswararao B, Kesavulu MM, Apparao C (2003) Evaluation of antidiabetic effect of Momordica cymbalaria fruit in alloxan-diabetic rats. Fitoterapia 74: 7-13.

6. Karau GM, Njagi ENM, Machocho AK, Wangai LN, Kamau PN (2012) Hypoglycemic Activity of Aqueous and Ethylacetate Leaf And Stem Bark Extracts of Pappea capensis in Alloxan-Induced Diabetic BALB/C Mice. British Journal of Pharmacology and Toxicology 3: 251-258.

7. Murugi NJ, Ngugi MP, Kibiti CM, Ngeranwa NJJ, Njagi ENM (2012) Evaluation of Antidiabetic effects of Kleinia squarrosa on alloxanized diabetic mice. Asian Journal of Biochemical and Pharmaceutical Research 2: 54-60.

8. Musila W, Kisangau D, Muema J (2002) Conservation Status and Use of Medicinal Plants by Traditional Medical Practitioners in Machakos District Kenya. National Museums of Kenya 22: 12-18.

9. Mahmood A, Mahmood A, Qureshi RA (2012) Antimicrobial activities of three species of family mimosaceae. Pakistan Journal of Pharmaceutical Sciences 25: 203-206.
10. Piero NM, Njagi MJ, Kibiti MC, Ngeranwa JNJ, Njagi NE, et al. (2012) Herbal Management of Diabetes Mellitus: A Rapidly Expanding Research Avenue. International Journal of Current Pharmaceutical Research 4.

11. Rajagopal K, Sasikala K (2008) Antihyperglycaemic and antihyperlipidaemic effects of Nymphaea stellata in alloxan-induced diabetic rats. Singapore Med J 49: 137-141.

12. Bailey CJ, Day C (1989) Traditional plant medicines as treatments for diabetes. Diabetes Care 12: 553-564.

13. Arika WM, Abdirahman YA, Mawia MA, Wambua KF, Nyamai DM, et al. (2015) In Vivo Antidiabetic Activity of the Aqueous Leaf Extract of Croton macrostachyus in Alloxan Induced Diabetic Mice. Pharmaceutica Analytica Acta 20: 15-19.

14. Szkudelski T (2001) The mechanism of alloxan and streptozotocin action in B-cells of the rat pancreas. Physiology Research 50: 536-546.

15. Roy K (2015) Medicinal Plants: Current Advancement and Approach in the Therapy of Diabetes Mellitus. Journal of Ethnopharmacology 1: 20-31.

16. Han C, Hui Q, Wang Y (2008) Hypoglycaemic activity of saponin fraction extracted from Momordica charantia in PEG/salt aqueous two-phase systems. Natural product research 22: 1112-1119.

17. Esmaeili MA, Yazdanparast R (2004) Hypoglycaemic effect of Teucrium polium: studies with rat pancreatic islets. J Ethnopharmacol 95: 27-30.

18. Sharma SB, Nasir A, Prabhu KM, Murthy PS (2006) Antihyperglycemic effect of the fruit-pulp of Eugenia jambolana in experimental diabetes mellitus. Journal of Ethnopharcology 104: 367-373.

19. Lombardo YB, Chicco AG (2006) Effects of dietary polyunsaturated n-3 fatty acids on dyslipidemia and insulin resistance in rodents and humans. A review. J Nutr Biochem 17: 1-13.

20. Ortiz-Andrade RR, Garcia-Jimenez S, Castillo-Espana P, Ramirez-AG, Molina RV (2007) Estrada-Soto S. a-Glucosidase inhibitory activity of the methanolic extract from Tournefortia hartwegiana: an antihyperglycemic agent. Journal of Ethnopharmacology 109: 48-53.

21. Obatomi DK, Bikomo EO, Temple VJ (1994) Anti-diabetic properties of the African mistletoe in streptozotocin-induced diabetic rats. J Ethnopharmacol 43: 13-17.

22. Middleton E Jr, Kandaswami C, Theoharides TC (2000) The effects of plant flavonoids on mammalian cells: implications for inflammation, heart disease, and cancer. Pharmacol Rev 52: 673-751.

23. Broadhurst CL, Polansky MM, Anderson RA (2000) Insulin-like biological activity of culinary and medicinal plant aqueous extracts in vitro. J Agric Food Chem 48: 849-852.

24. Li F1, Li Q, Gao D, Peng Y (2009) The optimal extraction parameters and anti-diabetic activity of flavonoids from Ipomoea batatas leaf. Afr J Tradit Complement Altern Med 6: 195-202.

25. Reher G, Slijepcevic M, Krans L (1991) Hypoglycemic activity of triterpenes and tannins from Sarcopoterium spinosum and two Sanguisorba Species. Planta Med 57: A57-A58.

26. Kako M, Miura T, Nishiyama Y, Ichimaru M, Moriyasu M, et al. (1997) Hypoglycemic activity of some triterpenoid glycosides. J Nat Prod 60: 604-605.

27. Kumari M, Jain S, Dave R (2014) Babul (Acacia nilotica) A. potential source of tannin and its suitability in management of type II diabetes. Nutrition and food science 2: 122-124.

28. Battin EE, Brumaghim JL (2009) Antioxidant activity of sulfur and selenium: a review of reactive oxygen species scavenging, glutathione peroxidase and metal-binding antioxidant mechanisms. Cell Biochemistry and Biophysics 55: 1-23.

29. O'Connell B (2001) Select vitamins and minerals in the management of diabetes. Diab Spectr 14: 133-148.

30. Percival M (1998) Antioxidants. Clinical Nutrition Insights 31: 1-4.

31. Rahimi R, Nikfar S, Larijani B, Abdollahi M (2005) A review on the role of antioxidants in the management of diabetes and its complications. Biomed Pharmacother 59: 365-373. 